Diterima: 03/02/2020, Direview: 07/05/2021, Diterbitkan: 31/10/2021

\title{
PENGEMBANGAN PROSES PEMBUATAN BIOETANOL GENERASI II DARI LIMBAH TANDAN KOSONG KELAPA SAWIT
}

\section{Development Of Process for Making Bioethanol Generation II from Palm Oil Empty Fruit Bunches Waste}

\author{
Hanifah Khairiah ${ }^{1 *}$, Muhammad Ridwan ${ }^{2}$ \\ 1) Program Studi Teknik Pengolahan Sawit, \\ 2) Program Studi Teknik Informatika \\ Politeknik Kampar, Jl. Tengku Muhammad KM 2 Bangkinang Kab. Kampar Riau \\ *Penulis Korespondensi, Email: hanifahkhairiah@gmail.com
}

\begin{abstract}
ABSTRAK
Tandan kosong kelapa sawit (TKKS) yang merupakan sumber gula mengandung selulosa yang tinggi (75-80\%), sehingga memiliki potensi besar untuk dijadikan bioetanol. Tujuan penelitian adalah menggunakan kembali tandan kosong kelapa sawit sebagai bahan utama dalam pembuatan bioetanol generasi II dengan melakukan pengembangan proses. Proses pertama yaitu pretreatment dengan menambahkan $\mathrm{NaOH}$ dan $\mathrm{H}_{2} \mathrm{SO}_{4} 2 \%$, dilanjutkan proses fermentasi menggunakan perbandingan Saccharomyces cerevisiae and Aspergillus oryzae dengan perbandingan $5,10,15$ dan $20 \%$ selama 7 hari. Terakhir adalah proses destilasi pada suhu $79^{\circ} \mathrm{C}$. Berdasarkan hasil penelitian, larutan $\mathrm{NaOH}$ lebih banyak menurunkan kadar lignin dan hemiselulosa sebesar $12.22 \%$ dan $45.17 \%$, sedangkan selulosa mengalami kenaikan sebesar $71.34 \%$. pada proses fermentasi, maka didapatkan variasi konsentrasi dan waktu optimum proses fermentasi pada penelitian ini adalah penambahan konsentrasi Saccharomyces cerevisiae 5\%, dengan volume bioetanol yang dihasilkan sebesar $14.4 \mathrm{ml}$, densitas $0.8757 \mathrm{~g} / \mathrm{ml}$ dan kadar glukosa yang tertinggal sebanyak $8.48 \%$.
\end{abstract}

Kata kunci : Bioetanol, Biomassa, Glukosa, Selulosa,tandan kosong kelapa sawit.

\section{ABSTRACT}

Palm oil empty bunches which is a source of sugar containing high cellulose (75-80\%), so it has great potential to be used as bioethanol. The purpose was to utilize empty oil palm bunches as raw material for the production of second-generation bioethanol. Pretreatment by adding $2 \% \mathrm{NaOH}$ and $\mathrm{H}_{2} \mathrm{SO}_{4}$, and the fermentation using a comparison of Saccharomyces cerevisiae and Aspergillus oryzae with a ratio of 5,10,15 and $20 \%$ for 7 days. The last is distillation at a temperature of $79^{\circ} \mathrm{C}$. Based on the research results, $\mathrm{NaOH}$ solution decreased lignin and hemicellulose levels by $12.22 \%$ and $45.17 \%$, while cellulose increased by $71.34 \%$.In the fermentation, variations of concentration and duration of fermentation that gave the best results in this study were addition of concentration of Saccharomyces cerevisiae by $5 \%$, with the volume of bioethanol produced by $14.4 \mathrm{ml}$, density $0.8757 \mathrm{~g} / \mathrm{ml}$ and glucose levels left as much as $8.48 \%$.

Keywords: Bioethanol, Biomass, Cellulose, Glucose, Palm oil empty bunches.

\section{PENDAHULUAN}

Kondisi persediaan energi di Indonesia saat ini mengalami ketidakseimbangan karena penyediaan energi tidak sebanding dengan kebutuhan. Cadangan minyak bumi nasional tahun 2015 terbukti mengalami penurunan 1.2\% dari tahun sebelumnya(British Petroleum, 2015). Sumber energi baru dan terbarukan (EBT) dapat menjadi solusi alternatif dalam memenuhi kebutuhan energi. Kebijakan tentang penggunaan 17\% total energi nasional pada tahun 2025 
berasal dari sumber EBT sudah diatur pada Peraturan Presiden RI No. 5 tahun 2006 (Peraturan Presiden, 2006).

Salah satu sumber EBT salah satunya bioetanol yang bisa digunakan sebagai pengganti bahan bakar minyak. Bioetanol merupakan EBT yang lebih ramah lingkungan. Proses reaksi etanol menghasilkan produk air dalam bentuk uap dan gas $\mathrm{CO}_{2}$ dalam jumlah yang lebih rendah dibanding bahan bakar minyak. Emisi karbon etanol yang rendah membuat bahan bakar etanol ini sebagai alternatif tepat untuk mengganti bahan bakar minyak bumi yang dianggap sebagai sumber gas rumah kaca terbesar (LIPI, 2011). Pemanfaatan bioetanol sebagai sumber EBT belum optimal dari segi ekonomi karena bioetanol belum bisa bersaing dengan energi berbasis bahan bakar fosil. Selain itu, salah satu penyebab utama mahalnya harga bioetanol adalah biaya produksi bioetanol yang relatif tinggi. Salah satu cara pengurangan biaya produksi bioetanol yaitu, dapat dilakukan melalui alternatif substitusi bahan baku, yang biasanya menggunakan bahan generasi pertama (Gl) seperti tanaman yang mengandung pati misalnya, pati ubi kayu, pati sagu, nira kelapa, nira batang sorgum, molasses dan sejenisnya yang dapat diubah sebagai bahan baku bioetanol dengan menggunakan bahan generasi kedua (GII). Bioetanol GIl dapat diperoleh dari bahan lignoselulosa, yaitu: TKKS, kayu-kayuan, bagas tebu, tongkol jagung, dan lain-lain (BPPPKP, 2014).

TKKS dalam ketersediaannya sangat berlimpah dan termasuk kedalam limbah padat dari industri minyak sawit (Nazir et al., 2013). Selain itu, TKKS merupakan sumber gula dengan kadar selulosa yang relatif tinggi (75-80\%), menunjukan TKKS dapat dijadikan bahan baku bioetanol yang baik (Tan et al., 2010). Produksi minyak sawit mentah terbesar tahun 2017 berasal dari Provinsi Riau sebesar 7.72 juta ton atau sekitar 22.40 persen dari total produksi Indonesia(Badan Pusat Statistik, 2017), menyebabkan produksi limbah padat TKKS melimpah di Provinsi Riau. Penelitian pemanfaatan TKKS menjadi bioetanol Gll perlu terus dikembangkan agar dapat mendukung ketersediaan EBT.

Berbagai penelitian terkait bioetanol telah dilakukan selama 5 tahun terakhir. Hasil penelitian sebelumnya, tahapan pembuatan bioetanol dapat dilakukan melalui tiga tahapan yaitu pretreatment, hidrolisis dan fermentasi (Pratiwi et al., 2013). TKKS pada proses pretreatment dengan menambahkan larutan $\mathrm{NaOH}$ yang bertujuan memutuskan ikatan lignin. Selanjutnya, proses hidrolisis menggunakan larutan $\mathrm{H}_{2} \mathrm{SO}_{4}$ dan difermentasi menggunakan ragi saccharomyces cerevisiae. Kadar etanol tertinggi pada penambahan larutan $\mathrm{H}_{2} \mathrm{SO}_{4} 20$ $\mathrm{mL}$ dengan fermentasi selama 6 hari, yaitu diperoleh kadar bioetanol tertinggi dihasilkan sebesar $7.12 \%$ (Pratiwi et al., 2013), sedangkan pada perlakuan penambahan larutan $\mathrm{H}_{2} \mathrm{SO}_{4}$ $2 \%$ dan fermentasi selama 2 hari diperoleh kadar etanol sebesar 4.94\% (Sartini et al., 2018). Berdasarkan penelitian tersebut, kadar etanol yang dihasilkan masih kurang optimal, sehingga diperlukan penelitian lebih lanjut seperti pengembangan proses dalam pembuatan bioetanol generasi kedua.

\section{BAHAN DAN METODE}

\section{Bahan}

Bahan pada penelitian ini adalah TKKS, $\mathrm{NaOH}$, asam sulfat, ragi Saccharomyces cerevisiae and Aspergillus oryzae, indikator pp, $\mathrm{HCl}$, asam asetat, aquades, aluminium foil, dan kertas lakmus.

\section{Alat}

Alat yang digunakan yaitu timbangan, Erlenmeyer, autoclave, shaker incubator, penyaring, oven, pisau, blender, ayakan 40-60 mesh, waterbath, hotplate, pipet mohr, buret, labu takar dan perangkat destilasi.

\section{Desain Penelitian}

Desain penelitian pada pengembangan proses pembuatan bioetanol Gll dari TKKS dapat dilihat pada Gambar.1. 


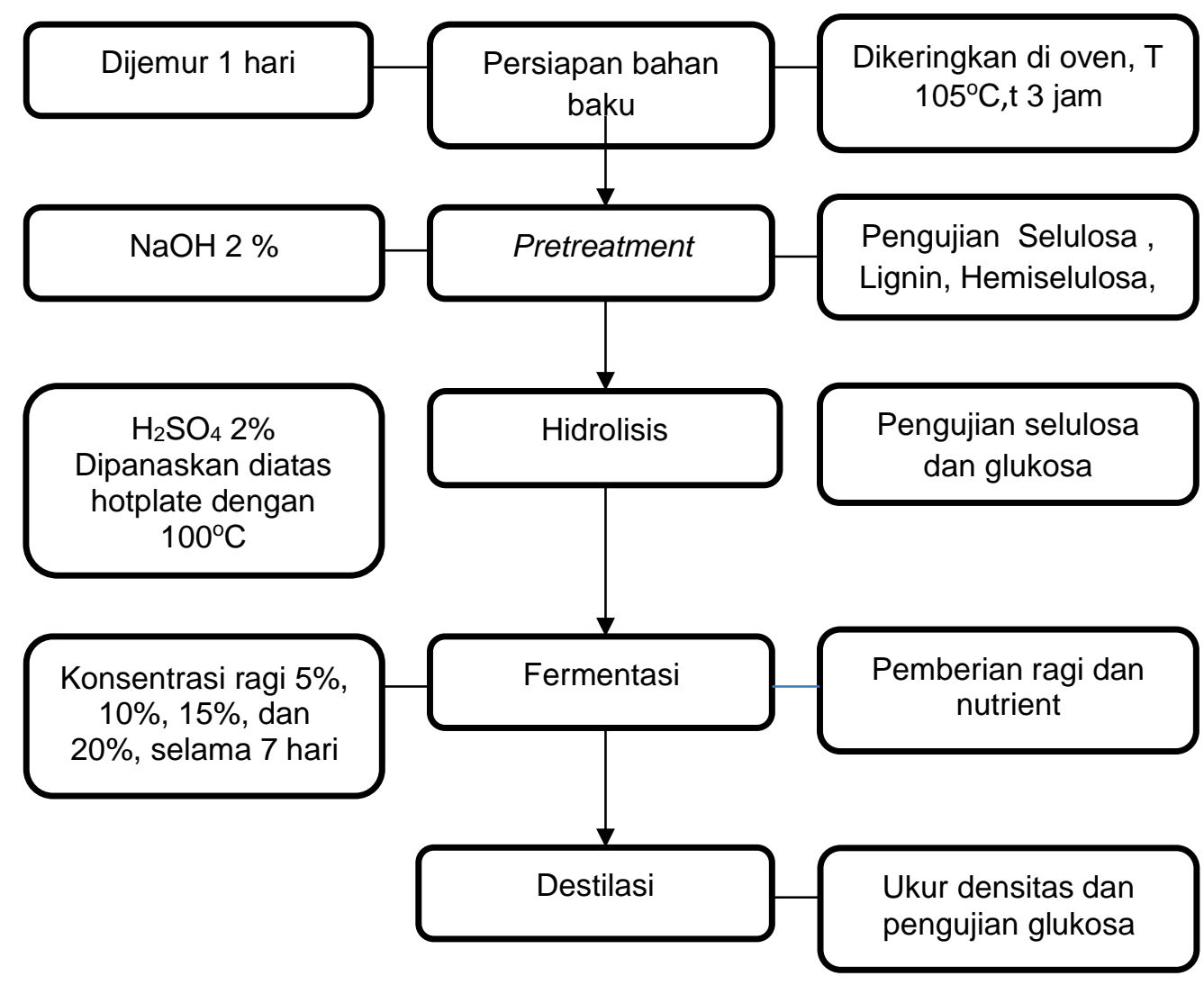

Gambar 1. Pengembangan Proses Pembuatan Bioetanol Gll dari TKKS

\section{Tahapan Penelitian}

Pembuatan bioetanol generasi II pada penelitian ini yaitu dengan melakukan pengembangan proses di setiap tahapan, agar diperoleh kadar bioetanol yang tinggi. Proses penelitian ini akan dilakukan 4 (empat) proses, yaitu pretreatment, hidrolisis, fermentasi, dan destilasi.

\section{Metode}

Persiapan sampel TKKS pertama kali dilakukan adalah TKKS dipotong pipih dan dikeringkan selama 1 hari, dipanaskan didalam oven suhu $80^{\circ} \mathrm{C}$ selama \pm 3 jam, dipotongpotong dengan ukuran $0.5-1 \mathrm{~cm}$, selanjutnya diblender untuk menghasilkan bubuk TKKS dan diayak menggunakan saringan 50 mesh. Tahapan pertama yaitu pretreatment dengan menambahkan larutan $\mathrm{NaOH} 2 \%$, lalu dipanaskan ke dalam autoclave suhu $121^{\circ} \mathrm{C}$ selama \pm 15 menit, dan dihomogenisasi menggunakan shaker incubator selama 1 hari (30 rpm, suhu $30^{\circ} \mathrm{C}$ ), selanjutnya penyaringan dan pembilasan dengan aquades sampai bersih dan dikeringkan di oven $\left(105^{\circ} \mathrm{C}\right)$ hingga konstan, lalu diperoleh residu selulosa. Lakukan pengujian lignin, hemiselulosa, dan selulosa sebelum dan sesudah pretreatment. Tahapan kedua yaitu proses hidrolisis dengan menggunakan $\mathrm{H}_{2} \mathrm{SO}_{4} 2 \%$, dipanaskan diatas hotplate dengan suhu $100^{\circ} \mathrm{C}$ selama 60 menit. Lakukan pengujian kadar selulosa sebelum dan sesudah. Lakukan penyaringan agar mendapatkan filtrat untuk proses fermentasi. Proses fermentasi menggunakan Saccharomyces cerevisiae and Aspergillus oryzae dengan perbandingan 5\%, $10 \%$, $15 \%$ dan $20 \%$, selanjutnya ditambahkan nutreat per $100 \mathrm{ml}$ sebanyak $1.2021 \mathrm{gr}$ $\left(\mathrm{NH}_{4}\right)_{2} . \mathrm{SO}_{4}, 0.1502 \mathrm{gr} \mathrm{MgSO}{ }_{4} .7 \mathrm{H}_{2} \mathrm{O}$ dan $0.1306 \mathrm{gr} \mathrm{KH}_{2} \mathrm{PO}_{4}$ tunggu selama 7 hari. Terakhir adalah proses destilasi pada suhu $79^{\circ} \mathrm{C}$ hingga etanol tidak menetes lagi, hasil etanol kemudian ditimbang dan diukur densitasnya. 


\section{Prosedur Analisis}

Prosedur Analisis yang dilakukan yaitu: pengujian sebelum dan sesudah pretreatment yaitu, kadar lignin, kadar selulosa, dan kadar hemiselulosa. Pada proses hidrolisis dilakukan pengujian selulosa. Pada proses fermentasi dilakukan beberapa pengujian yaitu, kadar glukosa, densitas, dan volume etanol

\section{HASIL DAN PEMBAHASAN}

\section{Pretreatment}

Pretreatment adalah proses utama yang dilakukan untuk menyederhanakan struktur lignoselulosa yang terdapat pada TKKS. Proses ini untuk menghancurkan lignin dan selulosa dan hemiselulosa menjadi senyawa gula yang lebih sederhana Selulosa dan hemiselulosa yang terbentuk kemudian akan lebih cepat dan efisien untuk dihidrolisis menjadi gula fermentasi (Kartika et al., 1992). Secara umum selulosa memiliki struktur kristalin yang merupakan bagian dari lignoselulosa mengandung mikrofibril homopolisakarida terdiri dari unit-unit D-glukopiranosa dan terhubung melalui ikatan glikosidik (Boedoyo et al., 2014). Sebelum dilakukan pretreatment, proses yang harus dilakukan adalah memotong dan menghaluskan TKKS yang untuk mengurangi ukuran lignoselulosa. Pengurangan ukuran lignoselulosa mempengaruhi porositas sehingga memaksimalkan kontak antara bahan dengan asam untuk meningkatkan hidrolisis hemiselulosa (Sun \& Cheng, 2002). Pada tahap ini TKKS dikeringkan dibawah terik matahari selama 1 hari kemudian dipanaskan didalam oven suhu $105^{\circ} \mathrm{C}$ selama \pm 3 jam bertujuan untuk mengurangi kadar air dan mempermudah proses pencacahan menggunakan blender. Setelah TKKS dikeringkan, TKKS kemudian di blender dan diayak menggunakan saringan 40-60 mesh agar diperoleh bubuk TKKS yang lebih kecil. Perlakuan awal TKKS dapat dilihat pada Gambar 2.

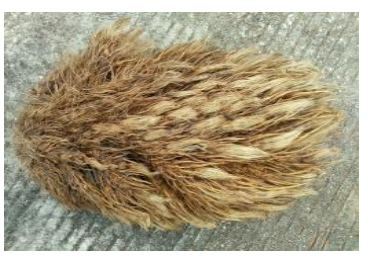

TKKS

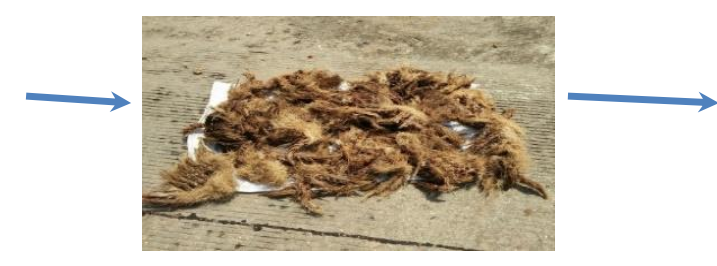

Pengeringan TKKS

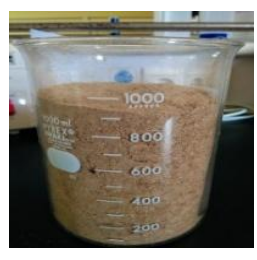

Bubuk TKKS

\section{Gambar 2. Perlakuan Awal TKKS}

Pada proses pretreatment TKKS dimasukkan sebanyak 20 gram ke dalam erlenmeyer dan ditambahkan $\mathrm{NaOH} 2 \%$ kemudian dimasukkan ke dalam autoclave pada suhu $121^{\circ} \mathrm{C}$ selama 20 menit. Penambahan $\mathrm{NaOH}$ menyebabkan selulosa merekah. Selulosa yang merekah mengakibatkan luas permukaan lignoselulosa semakin meningkat, mengakibatkan pemecahan dan pemisahan lignin dengan selulosa, atau menurunkan kandungan lignin pada lignoselulosa. Kemudian TKKS setelah di panas kan di homogenisasi menggunakan shaker incubator selama 1 hari (50 rpm, suhu $30^{\circ} \mathrm{C}$ ). Ikatan lignin mengakibatkan kinerja enzim tidak dapat maksimal (Moilanen et al., 2011) dan menghambat masuknya enzim ke dalam biomassa melalui ikatan lignin karbohidrat (Yu et al., 2014).Setelah itu lakukan pembilasan TKKS dengan aquades sampai pH netral. Setelah itu lakukan pengeringan di oven sampai berat sampel konstan. Kemudian lakukan pengujian kandungan lignin, selulosa dan hemiselulosa pada saat sebelum dan sesudah pretreatment. Perubahan sebelum dan sesudah pretreatment untuk mengetahui persentase pemekaran selulosa. Perubahan proses pretreatment sebelum dan sesudah dapat dilihat pada Gambar 3. 


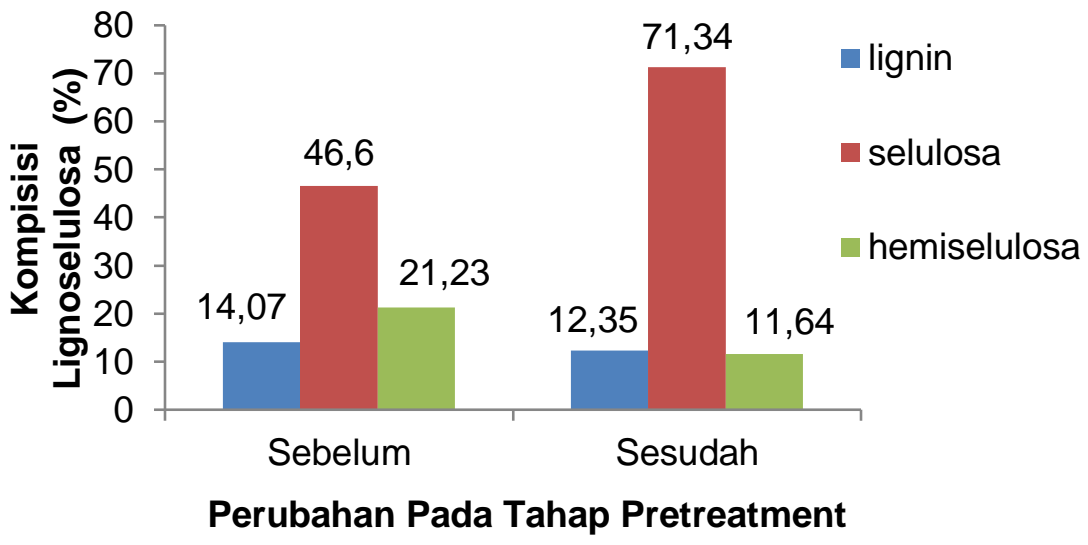

Gambar 3. Perubahan Sebelum dan Sesudah Pretreatment

Dari Gambar 3 menunjukkan bahwa lignin dan hemiselulosa mengalami penurunan, sebesar $12.22 \%$ dan $45.17 \%$, sedangkan selulosa mengalami kenaikan sebesar $53.09 \%$. Dapat disimpulkan pretreatment yang dilakukan telah berhasil. pretreatment yang dikatakan berhasil jika persentase selulosa naik. Kenaikan persentase selulosa menunjukkan bahwa selulosa dapat diakses dengan mudah saat proses hidrolisis (Feriandi, 2012). Kenaikan persentase selulosa menunjukkan bahwa selulosa dapat diakses dengan mudah saat proses hidrolisis (Kumar et al., 2009). Ikatan selulosa dalam biomassa diubah menjadi bioetanol melalui proses selanjutnya yaitu, hidrolisis, fermentasi dan destilasi.

\section{Hidrolisis}

Proses selanjutnya adalah hidrolisis untuk memisahkan ikatan dan mengurangi ikatan lignin dan hemiselulosa serta memecah struktur ikatan selulosa menjadi gula sederhana (Feriandi, 2012). Setelah residu pada tahap pretreatment telah konstan selanjutnya dilakukan penambahan asam sulfat $\left(\mathrm{H}_{2} \mathrm{SO}_{4}\right) 2 \%$. Hidrolisis asam memiliki tujuan agar lignoselulosa dapat menghasilkan monomer gula dari polimer selulosa dan hemiselulosa.akibat penambahan asam pada suhu $100^{\circ} \mathrm{C}$ yang dipanaskan di waterbath selama 120 menit . Tujuan pemanasan ini yaitu, untuk menghasilkan glukosa yang maksimal karena adanya laju reaksi yang cepat. Kemudian lakukan pengujian kandungan selulosa sebelum dan sesudah hidrolisis dan pengujian kadar glukosa setelah hidrolisis. Perubahan kandungan selulosa pada proses hidrolisis dapat dilihat pada Gambar 4.

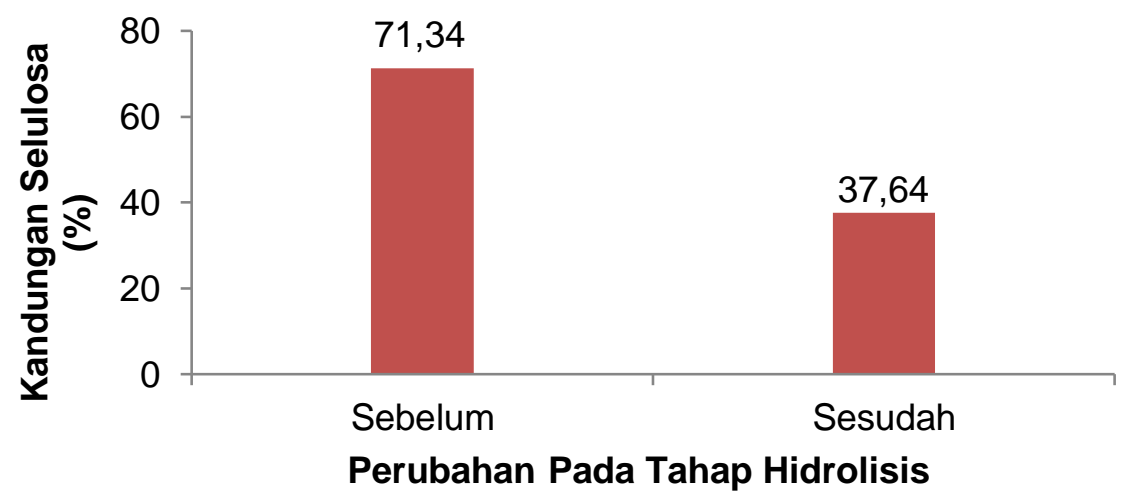

Gambar 4. Perubahan Kadar Selulosa Sebelum Dan Sesudah Hidrolisis

Berdasarkan Gambar 4. Menunjukkan selulosa sesudah hidrolisis mengalami penurunan sebesar $48.93 \%$ dikarenakan selulosa yang didapat setelah pretreatment diubah menjadi glukosa pada tahap hidrolisis, sehingga glukosa dapat difermentasi menjadi etanol 
dengan baik.

\section{Fermentasi}

Fermentasi merupakan proses pemisahan karbohidrat menjadi etanol dan karbon dioksida yang dihasilkan oleh mikroba yang disebut jamur dan dalam keadaan tidak ada udara atau anaerob (Satyawibawa et al., 2004). Pada percobaan ini menggunakan Saccharomyces cerevisiae and Aspergillus oryzae sebagai pengurai untuk mengubah kadar glukosa menjadi etanol.

Setelah pada tahap hidrolisis selulosa yang telah dirubah menjadi glukosa akan difermentasikan menggunakan mikroba untuk merubah glukosa menjadi etanol (Pratiwi et al., 2013). Pada tahap ini dilakukan penambahan variasi Saccharomyces cerevisiae and Aspergillus oryzae sebanyak $5 \%, 10 \%, 15 \%$, dan $20 \%$ pada waktu proses fermentasi selama \pm 7 hari. Proses fermentasi dapat dilihat pada Gambar 5 .

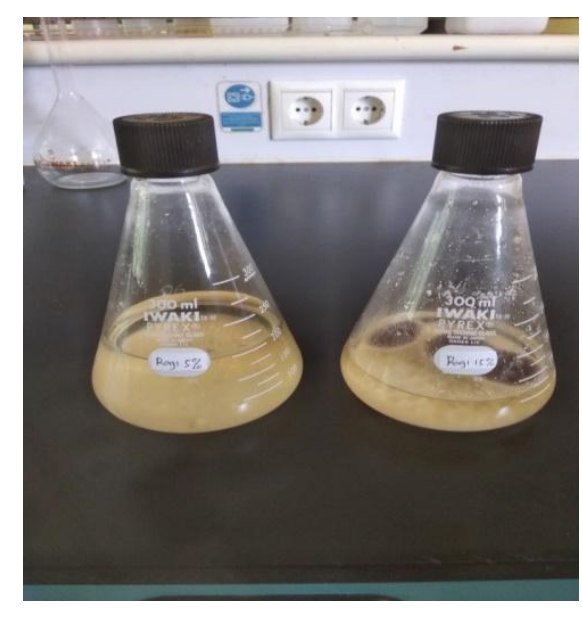

Gambar 5. Hasil Proses Fermentasi

\section{Destilasi}

Proses destilasi merupakan proses pengembunan kembali atau penguapan untuk memisahkan etanol dari larutan hasil fermentasi selama 7 hari, dengan suhu $70-80^{\circ} \mathrm{C}$ sampai etanol tidak menetes lagi. Setelah itu hitung volume yang di dapat, serta lakukan pengujian densitas dan kadar glukosa. Berikut Tabel 1. Volume, Densitas Setelah Fermentasi Serta Kadar Glukosa sebelum dan sesudah fermentasi.

Tabel 1. Volume Dan Densitas Sesudah Fermentasi

\begin{tabular}{ccccc}
\hline Konsentrasi & \multicolumn{2}{c}{ Volume $(\mathrm{ml})$} & \multicolumn{2}{c}{ Densitas (gr/ml) } \\
\cline { 2 - 5 } Ragi & $\begin{array}{c}\text { Saccharomyces } \\
\text { cerevisiae }\end{array}$ & $\begin{array}{c}\text { Aspergillus } \\
\text { oryzae }\end{array}$ & $\begin{array}{c}\text { Saccharomyces } \\
\text { cerevisiae }\end{array}$ & $\begin{array}{c}\text { Aspergillus } \\
\text { oryzae }\end{array}$ \\
\hline $5 \%$ & 14.4 & 9.5 & 0.8757 & 0.9231 \\
$10 \%$ & 9.6 & 6.5 & 0.9121 & 0.9335 \\
$15 \%$ & 9.4 & 6.2 & 0.8739 & 0.9323 \\
$20 \%$ & 8.5 & 5.4 & 0.8910 & 0.9296 \\
\hline
\end{tabular}

Berdasarkan Tabel 1, densitas ragi Saccharomyces cerevisiae yang diperoleh sudah mendekati densitas etanol atau sekitar 0,87-0,91 gr/ml. Semakin tinggi densitasnya maka akan semakin rendah kadar etanol (Pratiwi et al., 2013). Setelah dilakukan destilasi lakukan pengujian kadar glukosa setiap masing-masing konsentrasi. Pengujian kadar glukosa hanya dilakukan pada hasil filtrasi ragi Saccharomyces cerevisiae, dikarenakan volume hasil filtrasi ragi Aspergillus oryzae tidak memenuhi standar densitas etanol. Pengujian kadar glukosa dapat dilihat pada Gambar 6. 


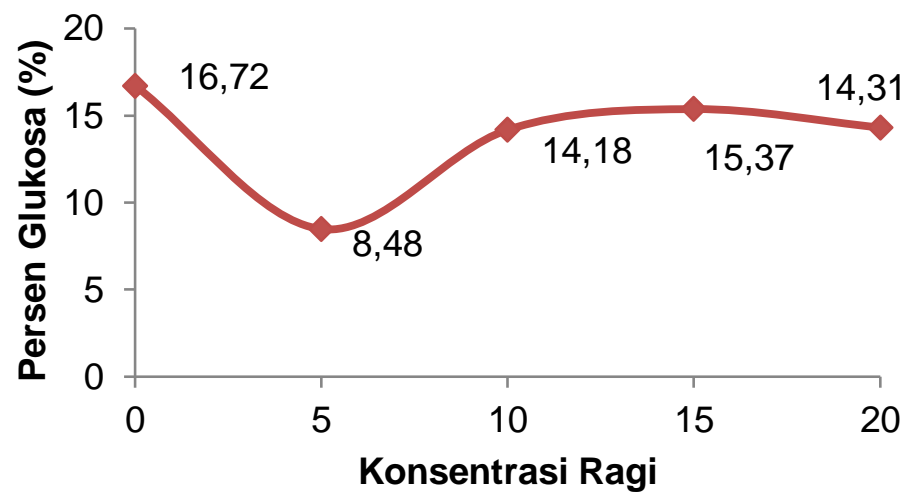

\section{Gambar 6. Pengaruh Proses Fermentasi Terhadap Penurunan Kadar Glukosa}

Berdasarkan Gambar 6, kadar glukosa yang diperoleh berada dibawah kadar glukosa sebelum fermentasi yaitu $16.72 \%$ sehingga proses fermentasi berjalan dengan baik. Variasi ragi $5 \%$ mempunyai kadar glukosa yang paling rendah dikarenakan glukosa yang telah dihidrolisis pada tahap sebelumnya sudah menjadi etanol pada saat fermentasi. Salah satu faktor yang mempengaruhi fermentasi etanol yaitu, lama fermentasi. Jika massa ragi banyak, maka akan mempercepat lama fermentasi dikarenakan banyaknya massa yang mengubah glukosa menjadi etanol. Sebaliknya jika massa ragi kecil maka akan menurunkan lama fermentasi karena sedikitnya massa yang mengubah glukosa menjadi etanol. (Pratiwi et al., 2013). Kenaikan kadar glukosa terjadi setelah fermentasi menggunakan ragi $10 \%$. Kenaikan kadar glukosa menggunakan ragi $10 \%$ disebabkan mikroba pada proses fermentasi berada pada fase kematian atau fase penurunan disebabkan media telah berkurang dan substrat serta nutrient sudah habis sedangkan jumlah mikroba masih dalam jumlah yang banyak, sehingga menyebabkan sel tidak mampu membelah dan berkembangbiak lagi.

\section{SIMPULAN}

Berdasarkan hasil penelitian ini, dapat disimpulkan bahwa bioetanol dari tandan kosong kelapa sawit (TKKS) melalui 4 tahapan proses, yaitu: pretreatment, hidrolisis, fermentasi, dan destilasi. Setelah dilakukan pretreatment kadar selulosa meningkat yang sebelumnya $46.6 \%$ menjadi $71.34 \%$, sebaliknya terjadi pengurangan pada lignin yang pada awalnya $14.07 \%$ menjadi $12.35 \%$. Pada tahap hidrolisis terjadi pengurangan jumlah selulosa yang awalnya $71.34 \%$ menjadi $37.64 \%$. Setelah dilakukan fermentasi, maka didapatkan konsentrasi ragi Saccharomyces cerevisiae sebanyak $5 \%$ dengan lama fermentasi 7 hari sebagai konsentrasi ragi dan lama fermentasi yang optimum. Setelah proses destilasi diperoleh volume bioetanol sebesar $14.4 \mathrm{ml}$ memiliki densitas $0.8757 \mathrm{~g} / \mathrm{ml}$ dengan kadar glukosa yang tertinggal sebanyak $8.48 \%$

\section{UCAPAN TERIMA KASIH}

Kepada Direktorat Riset dan Pengabdian Masyarakat Kementerian Riset, Teknologi dan Pendidikan Tinggi, dan Pusat Penelitian dan Pengabdian Masyarakat (P3M) Politeknik Kampar Saya sampaikan ucapan terima kasih atas dukungan dana penelitian dalam penyelesaian penelitian ini.

\section{DAFTAR PUSTAKA}

Badan Penelitian dan Pengembangan Pertanian Kementrian Pertanian. (2014). Biofuel Generasi 1 dan Generasi 2. Jakarta: Badan Penelitian dan Pengembangan Pertanian Kementrian Pertanian. 
Badan Pusat Statistik. (2017). Statistik Kelapa Sawit. Jakarta: BPS.

Boedoyo, M. ., Wahid, L. O. M. ., Fitriana, I., Niode, N., Puspita, R. ., Siregar, E., Paminto, A. ., Suarna, E., Wijaya, P. ., Kismanto, A., Raksodewanta, A. ., Yudiartono, Sugiyono, A., Suryani, Anindhita, Fitriana, I., \& Gustiani, N. (2014). Outlook Energi Indonesia 2014: Pengembangan Energi Untuk Mendukung Program Subsitusi BBM (Anindhita., M. S. Boedoyo., \& Adiarso (eds.)). Pusat Teknologi Pengembangan Sumberdaya Energi. Badan Pengkajian Dan Penerapan Teknologi. ISBN 978-6021328-02-6. Jakarta.

British Petroleum. (2015). Statistical Review of World Energy June. British: BP Stat.Rev. World Energy.

Feriandi. (2012). Kajian Perlakuan Awal Secara Kimiawi dan Enzimatik Limbah Tandan Kosong Kelapa Sawit (TKKS) Menjadi Gula Reduksi Sebagai Bahan Baku Bioetanol. Universitas Lampung. Bandar Lampung.

Kartika, B., Guritno, A. D., Purwadi, D., \& Ismoyowati, D. (1992). Petunjuk Evaluasi Produk Industri Hasil Pertanian. PAU Pangan Dan Gizi UGM. Yogyakarta.

Kumar, P., Barrett, D. M., Delwiche, M. J., \& Stroeve, P. (2009). Methods for Pretreatment of Lignocellulosic Biomass for Efficient Hydrolysis and Biofuel Production. Industrial \& Engineering Chemistry Research, 48(8), 3713-3729. https://doi.org/10.1021/ie801542g

LIPI. (2011). Biofuel Generasi Kedua, dari Rumput dan Limbah. Lembaga IImu Pengetahuan Indonesia.

Moilanen, U., Kellock, M., Galkin, S., \& Viikari, L. (2011). The laccase-catalyzed modification of lignin for enzymatic hydrolysis. Enzyme and Microbial Technology, 49(6-7), 492-498. https://doi.org/10.1016/j.enzmictec.2011.09.012

Nazir, M. S., Wahjoedi, B. A., Yussof, A. W., \& Abdullah, M. A. (2013). Eco-Friendly Extraction and Characterization of Cellulose From Oil Palm Empty Fruit Bunches. BioRes, 8(2), 2161-2172.

Peraturan Presiden Republik Indonesia Nomor 5 Tahun 2006. (2006). Tentang Kebijakan Energi Nasional.

Pratiwi, R. A., Amelia, R., \& Moeksin, R. (2013). Pengaruh Volume Asam (Proses Hidrolisis) Dan Waktu Fermentasi Pada Pembuatan Bioetanol Dari Tandan Kosong Kelapa Sawit. Jurnal Teknik Kimia, 19(1), 50-53.

Sartini, S., Fitriani, R., \& Lubis, R. (2018). Pengaruh Kadar asam Sulfat Pada Hidrolisis Tandan Kosong Kelapa Sawit (TKS) dan Waktu Fermentasi Terhadap Kadar Bioetanol yang dihasilkan. BioLink. Jurnal Biologi Lingkungan, Industri, Kesehatan, 4(2), 154-161.

Satyawibawa, I., Widyastuti, Y. E., Fauzi, Y., \& Rudi, H. (2004). Kelapa Sawit; Budi Daya;Pemanfaatan Hasil Dan Limbah;Analisis Usaha Dan Pemasaran. Penebar Swadaya. Jakarta.

Sun, Y., \& Cheng, J. (2002). Hydrolysis of lignocellulosic materials for ethanol production: a review. Bioresource Technology, 83(1), 1-11. https://doi.org/10.1016/S09608524(01)00212-7

Tan, H. T., Lee, K. T., \& Mohamed, A. R. (2010). Second-generation bio-ethanol (SGB) from Malaysian palm empty fruit bunch: Energy and exergy analyses. Bioresource Technology, 101(14), 5719-5727. https://doi.org/10.1016/j.biortech.2010.02.023

Yu, Z., Gwak, K.-S., Treasure, T., Jameel, H., Chang, H., \& Park, S. (2014). Effect of Lignin Chemistry on the Enzymatic Hydrolysis of Woody Biomass. ChemSusChem, 7(7), 19421950. https://doi.org/10.1002/cssc.201400042 